\title{
The Relationship Between Chaebol And Firm Value Using Bayesian Network
}

\author{
Eun-Jung Sun, Hannam University, South Korea
}

Sung-Jin Park, Sungshin Women's University, South Korea

\begin{abstract}
The purpose of this study is to analyze the effects of being a chaebol company, the biggest company characteristic variable, on firm value. It tries to overcome the limitation of multiple regression analysis mostly used in preceding research. That is, as multiple regression analysis assumes uniform linearity between dependent and independent variables, it could not reflect the diverse types of the real world. Thus, based on being a chaebol company and financial information, company characteristic variables influencing firm value, this study derives causal relationships existing between them. The results could help managers and various accounting information users in their decision-making by providing them with information of what company characteristics would directly or indirectly influence firm value. To this end, this study utilizes Bayesian Network and attempts Markov Blanket. In the end, all the analysis methods used in this study not only provides significant results, but also raises its practical value by offering information of diverse situations that could occur in the real world.
\end{abstract}

Keywords: Chaebol Companies; Firm Value; Bayesian Network; Sensitivity Analysis

\section{INTRODUCTION}

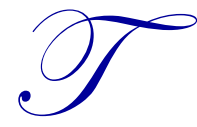

his study analyzes what company characteristics various information users should focus on to improve firm value. Especially, it concentrates on the effects of being a chaebol company, among diverse company characteristics, on firm value. A chaebol company is a firm, included in a group of large-size companies, which is legally independent but is managed like a business department under a single head. As chaebol companies are greatly influencing many industry fields in Korea, it is important to analyze how being a chaebol company would influence firm value in the capital market. In the past, although chaebol companies were the driving force behind the rapid growth of Korea through mass production and exportation, some had problems related to ownership and control due to cross-shareholding, and some damaged fair market order owing to their monopoly behavior. Thus, it should be vital to examine how investors would assess Korean chaebol companies and analyze their financial characteristics.

Although there are many preceding studies on chaebol, they have two limitations as follows. First, they agreed that being a chaebol company would somehow be related to firm value (McNeil, Niehaus, \& Powers, 2004; Khanna \& Palepu, 2000; Campbell \& Keys, 2002; Berger \& Ofek, 1995; Stulz, 1990; Lewellen, 1971), but none of them derived causal relationships between company characteristic variables including being a chaebol company to provide decision makers with diverse pieces of related information. Second, none of them analyzed the relationships between various company characteristic variables to innovatively improve firm value. As many company characteristic variables including being a chaebol company could complexly influence firm value, it was limited to explain firm value simply with one-dimensional linearity. In short, there are few studies specifically analyzing especially what company characteristic variables would ultimately influence firm value.

Thus, this study intends to overcome the existing problems and clearly examine causal relationships hidden between company characteristics that could statistically and meaningfully identify firm value. To this end, this study uses Bayesian Network, and based on it, suggests Markov Blanket. In addition, it conducts sensitivity analysis on each company characteristic to examine company characteristic variables that would greatly influence firm value in the various types of the real world. 
Bayesian Network, frequently used in this study, is widely known as an analysis method to compare and analyze the relationships between the pieces of information containing much uncertainty (Neapolitan, 2004). Especially, as regression analysis, mostly used in preceding studies, assumes uniform linearity between dependent and independent variables, it has a limitation that it cannot represent the real world. Thus, the problems arising from these preceding studies should be resolved. In other words, causal relationships, including direct and indirect ones, existing between diverse company characteristic variables influencing firm value should be derived. The results would offer rich information to managers and decision makers having much interest in improvement of firm value.

This study tries to grasp the relationships between firm value and company characteristic variables by targeting the samples of chaebol companies (2006-2015) provided by Fair Trade Commission (FTC) and 6,602 firm-years from New-KISVALUE of Nice Information Service. The results would practically contribute to various information users' decision-making by providing them with information on what company characteristic variables they should focus on to improve firm value.

This study consists of 5 chapters. Following Chapter 1, Introduction, Chapter 2 examines preceding studies and the background knowledge of this study. It first reviews the meaning of chaebol and its effectiveness referring to preceding studies. Chapter 3, Research Design, examines research procedure, and data collection and variable measuring methods. Especially, it investigates how to measure firm value and financial characteristic variables and how to categorize the variables. Chapter 4, Research Results, analyzes descriptive statistics of the variables used in this study, and then conducts sensitivity analysis considering causal relationships between the variables and the various types of the real world based on Bayesian. Lastly, Chapter 5, Conclusion, summarizes the empirical analysis results of this study and comments on its academic and practical implications.

\section{REVIEW ON BACKGROUND KNOWLEDGE AND PRECEDING STUDIES}

\subsection{The Meaning of Chaebol}

In Korea, although a firm belonging to a group of large-size companies is legally independent, if it is managed like a business department under a single head, it is called a 'chaebol company' and said to perform 'chaebol management' (Kang, 1999; Park, Sung, \& Jung, 2010). Particularly in Korea, a small number of individuals and their families own chaebol companies monopolistically controlling the market, and accordingly these chaebol companies are exerting great influence on industry fields (e.g. manufacturing industry, distribution industry, cultural art industry, etc.).

Chaebol companies within a chaebol group are sharing all sorts of resources (e.g. economic resources, human resources, etc.), and their governance structures are complexly connected through mutual investment and internal transaction between them (Chang, 2003). Thus, chaebol companies can utilize the whole resources of their chaebol group, and they have an independent labor market within their own chaebol group, which allows active transfer of personnel. Moreover, common use and distribution of the resources within chaebol companies would promote vertical systemization of industries within a chaebol group.

Although chaebol companies within a chaebol group are legally independent, actually they are controlled by a single head (Chang and Shin, 2006). Especially, the division controlling chaebol companies, which has various names such as corporate restructuring office or business strategy office, makes medium- and long-term development plans for a chaebol group, manages the managers of chaebol companies, and collects related information. Controlling chaebol companies is known to raise the firm value of the whole chaebol group (Chang \& Hong, 2000). In addition, as a chaebol group can easily gain management information of chaebol companies and make them more effective, it can improve management performance of chaebol companies better than nonexecutive directors (McNeil et al., 2004).

These chaebol companies led economic growth of Korea in the past through mass production and exportation and greatly contributed to Korean economic development through creation of employment. However, these chaebol companies have problems related to ownership and control due to cross-shareholding, and some conduct monopoly behavior damaging fair market order. In order to correct these side effects, FTC is designating and regulating 'a group of large-size companies' or 'a group of companies limited to make mutual investment'. The number of 
chaebol companies has increased from 567 in 2000 to 1,128 in 2016. FTC is making an effort to prevent chaebol companies from conducting market disturbing behavior and establish fair and healthy market order through prohibition on mutual investment, limitation on guarantee for obligation, and enhancement of disclosure system.

\subsection{The Effectiveness of Chaebol}

The biggest characteristic of the industry structure of Korea is that there are chaebol companies exerting their monopoly status in each industry field. Chaebol companies included in a chaebol group have diverse characteristics in relation to management activity and capital finance. First, chaebol companies have a highly diversified business structure (Chang \& Hong, 2000). In other words, although chaebol companies included in a chaebol group are legally independent, they are actually being controlled by the head of the chaebol group, and this governance structure leads to a complex relation of stock ownership. For example, chaebol companies' mutual ownership of stocks and their pyramidal stock ownership structure enable the head (and his or her family) of the whole chaebol group to control it with a small share ratio.

In addition, a control office of a chaebol group (e.g. corporate restructuring office, business strategy office, etc.) distributes resources of the whole chaebol group, and designs and connects medium- and long-term strategic business goals for chaebol companies (Chang \& Shin, 2006). Moreover, while non-chaebol companies carry out their assessment and compensation through the board of directors, for chaebol companies, a control office engages in their medium- and long-term management activity, distributing the labor force of their chaebol group (Shin \& Chang, 2005). Therefore, it is highly likely that chaebol companies within a chaebol group can secure talented manpower compared to other companies.

Many studies are being conducted on the effectiveness of chaebol companies both in domestic and foreign countries, especially on the effects of management activity of chaebol companies included in a chaebol group on firm value. For example, one study reported that firm value of chaebol companies included in a chaebol group would be generally high (Khanna \& Palepu, 2000), and another argued that while chaebol companies would have a high growth rate of sales, they would tend to show a low level of management performance (Campbell \& Keys, 2002).

The complex governance structure of a chaebol group could spread risks through business diversification (Khanna \& Palepu, 2000). In addition, as chaebol companies within a chaebol group are diversified, the effectiveness of management could improve through integration of specialized business units, which could result in a synergy effect and high profitability (Berger \& Ofek, 1995). Further, business diversification within a chaebol group could contribute to not only efficient distribution of internal resources, which could raise the effectiveness of investment (Stulz, 1990), but also integration of various business units of chaebol companies, which could enhance the ability to bear debt. That is, a chaebol group can receive positive assessments from the government and outside investors by using its monopoly status in each industry field. Thus, chaebol companies can have an enhanced ability to bear debt compared to other companies and secure rich liquidity through guarantee for obligation and mutual investment among them (Stein, 1997). As a result, considering the capital structure, chaebol companies are using more debts than other companies. By using this ability to bear debt, a chaebol group can maximize the tax shield effect (Lewellen, 1971). However, the complexity due to business diversification of a chaebol group could lead to corporate uncertainty (Klein, 2002).

\section{RESEARCH DESIGN}

\subsection{Research Procedure and Data Collection}

This study aims to examine the company characteristics influencing firm value and grasp the relationships between company characteristic variables. To this end, Bayesian Network and sensitivity analysis are used to infer the meaning that the variables have in the diverse types of the real world. Particularly, sensitivity analysis is used to assume various scenarios for company characteristics represented by characteristic variables, and reflecting the diverse types of the real world, to examine how much the change in each variable would influence others based on the probabilistic causal relationships derived through Bayesian Network. Research procedure can be summarized as follows. First is to collect data for the empirical analysis of this study. Second is to derive a causal relationship graph 
of the data collected through Bayesian Network. Last is, based on an assumption of the diverse types of the real world, to examine how the change in each variable would influence others and investigate the practical meaning of the change.

The samples used for the empirical analysis of this study are made between 2006 and 2015. During the analysis period, among companies listed on the stock market, those satisfying all the requirements below are targeted as samples and analyzed: (1) Those engaged in the manufacturing industry, (2) those whose closing date of the fiscal year is December 31, and (3) those that could provide available financial statements needed for this study. As financial business has different characteristics from other industry fields, it is excluded from this study to promote comparability during the analysis period. In addition, for cross-sectional analysis using annual materials related to settlement of accounts, only companies whose closing date of the fiscal year is December 31 are targeted to increase homogeneity of the samples. As for financial data, information data from New KISVALUE of Nice Information Service is used, and as for being a chaebol company, data publically announced by FTC (e.g. a group of large-size companies, a group of companies limited to make mutual investment, etc.) is used. The samples finally used for the analysis are 6,602 firm-years. Table 1 shows the number of samples more specifically by year.

\begin{tabular}{|l|c|c|c|c|c|c|c|c|c|c|c|c|}
\multicolumn{10}{c}{ Table 1. Number of samples } \\
\hline \multicolumn{1}{|c|}{ Year } & $\mathbf{2 0 0 6}$ & $\mathbf{2 0 0 7}$ & $\mathbf{2 0 0 8}$ & $\mathbf{2 0 0 9}$ & $\mathbf{2 0 1 0}$ & $\mathbf{2 0 1 1}$ & $\mathbf{2 0 1 2}$ & $\mathbf{2 0 1 3}$ & $\mathbf{2 0 1 4}$ & $\mathbf{2 0 1 5}$ & Total \\
\hline Chaebol & 127 & 136 & 117 & 130 & 141 & 146 & 159 & 155 & 145 & 131 & 1,387 \\
\hline Non-Chaebol & 505 & 516 & 522 & 524 & 512 & 527 & 522 & 531 & 526 & 530 & 5,215 \\
\hline Total & 632 & 652 & 639 & 654 & 653 & 673 & 681 & 686 & 671 & 661 & 6,602 \\
\hline
\end{tabular}

\subsection{Measurement of Variables}

\subsubsection{Firm Value}

Among various ways of measuring firm value, the most typical method is Tobin's Q. Generally, Tobin's Q is calculated dividing market value of a company by replacement cost of the company. For example, if company value assessed by the capital market is high, Tobin's $Q$ turns out to be high, because intrinsic firm value is high. Besides, as it is very difficult to measure replacement cost of a company, generally replacement cost is measured using book value of the company (Chung \& Pruitt 1994; Jang \& Choi 2010; Na \& Hong, 2011). In addition, as it is hard to measure market value of debt, and as there is little difference between market value and book value of debt, the former is usually replaced by the latter (Jang \& Choi 2010; Na \& Hong, 2011).

\subsubsection{Financial Characteristic Variables}

This study determines company characteristics using company financial variables. The company financial characteristic variables used in this study were return on assets (ROA), growth rate of sales (Growth), R\&D expenditure ratio (RNDtoS), debt ratio (LEV), capital intensity (Cap_Intensity), company size (Size), operating cash flow (OCF), and being a chaebol company (Chaebol). Return on assets (ROA) is the most typical index to measure how effectively assets are used. In other words, it is an index to show how much return can be created with minimum assets. While the numerator of this index is a flow concept representing profitability during a certain period, the denominator is a stock concept showing assets on a certain point. Merely, as it is difficult to precisely measure assets on the denominator during a certain period, the denominator is normally the average value of assets during a certain period (or on a certain point) (Song, Yun, \& Choi, 2014). Thus, in this study, return on assets is calculated dividing net income (numerator) by total assets (denominator).

Many studies used growth rate of sales (Growth) and R\&D expenditure ratio (RNDtoS) to represent possibility of company growth, reporting that possibility of company growth would have positive effects on firm value (Francis \& Schipper, 1999; Pástor \& Veronesi, 2003; Rountree, Weston, \& Allayannis, 2008). Accordingly, this study included growth rate of sales (Growth) and R\&D expenditure ratio (RNDtoS) in company characteristic variables. Besides, growth rate of sales (Growth) is calculated dividing the difference between sales of the precious year and that of the 
current year by sales of the precious year, and R\&D expenditure ratio (RNDtoS) is measured dividing expenditure for R\&D by sales.

When a company raises funds using debt, shareholders tend to transfer creditors' wealth to themselves by replacing businesses having low investment risks with businesses having high investment risks (Jensen \& Mecking, 1976). That is, managers raise funds from creditors at low interest rates based on the pretext that they would invest in businesses having low investment risks, and then they actually invest in businesses having high investment risks using the funds to transfer creditors' wealth to shareholders. In addition, excessive fund raising from creditors could increase possibility of bankruptcy and thereby decrease firm value, which could cause conflicts between shareholders and creditors regarding their interest, resulting in generation of various types of cost such as bankruptcy cost having negative effects on firm value. Thus, this study included debt ratio (LEV) in company characteristic variables, and it is calculated dividing total liabilities by total assets.

If capital intensity (Cap_Intensity) is high, earning volatility becomes high due to operating leverage. Thus, when capital intensity is high, normally firm value becomes low (Baginski, Lorek, Willinger, \& Branson, 1999; Lev, 1983). Capital intensity (Cap_Intensity) is calculated using the ratio of tangible assets (e.g. lands, buildings, machines, office fixtures, etc.) to total assets.

Lastly, this study includes operating cash flow (OCF) and company size (Size) used in a preceding study (Kang, Lee, \& Choi, 2009) in company characteristic variables. Here, operating cash flow (OCF) is calculated dividing operating cash flow of statement of cash flow by total assets, and company size (Size) is measured by calculating the natural logarithm of total assets.

\subsection{Categorization of Variables}

The variables used in this study to examine the relationship between being a chaebol company and financial characteristics influencing firm value are shown in Table 2. To use Bayesian Network, an analysis method used in this study, it is needed to categorize variables. Thus, all the company characteristic variables used in this study are categorized into three groups at equal frequency, except for R\&D expenditure ratio (RNDtoS) and being a chaebol company (Chaebol). R\&D expenditure ratio (RNDtoS) and being a chaebol company (Chaebol) are divided into two groups. 


\begin{tabular}{|c|c|c|c|c|}
\hline Variables & Definition of Variables & Criter & egorization & Categorization \\
\hline \multirow{3}{*}{ TobinQ } & \multirow{3}{*}{ Company's Value } & Low & $\sim 0.763$ & \multirow{3}{*}{3 equal frequency } \\
\hline & & Mid & $0.763 \sim 1.033$ & \\
\hline & & High & $1.033 \sim$ & \\
\hline \multirow{3}{*}{ ROA } & \multirow{3}{*}{ Return on Assets } & Low & $\sim 0.017$ & \multirow{3}{*}{3 equal frequency } \\
\hline & & Mid & $0.017 \sim 0.060$ & \\
\hline & & High & $0.060 \sim$ & \\
\hline \multirow{3}{*}{ OCF } & \multirow{3}{*}{ Operating Cash Flows } & Low & $\sim 0.021$ & \multirow{3}{*}{3 equal frequency } \\
\hline & & Mid & $0.021 \sim 0.082$ & \\
\hline & & High & $0.082 \sim$ & \\
\hline \multirow{3}{*}{ Growth } & \multirow{3}{*}{ Sales Growth Rate } & Low & $\sim-0.058$ & \multirow{3}{*}{3 equal frequency } \\
\hline & & Mid & $-0.058 \sim 0.068$ & \\
\hline & & High & $0.068 \sim$ & \\
\hline \multirow{3}{*}{ Cap_Intensity } & \multirow{3}{*}{ Capital Intensity } & Low & $\sim 0.258$ & \multirow{3}{*}{3 equal frequency } \\
\hline & & Mid & $0.258 \sim 0.430$ & \\
\hline & & High & $0.430 \sim$ & \\
\hline \multirow{2}{*}{ RNDtoS } & \multirow{2}{*}{ R\&D Expense over Sales } & Low & $\sim 0.004$ & \multirow{2}{*}{ Binary } \\
\hline & & High & $0.004 \sim$ & \\
\hline \multirow{3}{*}{ Size } & \multirow{3}{*}{ Log of Total Assets } & Low & $\sim 25.639$ & \multirow{3}{*}{3 equal frequency } \\
\hline & & Mid & $25.639 \sim 26.805$ & \\
\hline & & High & $26.805 \sim$ & \\
\hline \multirow{3}{*}{ LEV } & \multirow{3}{*}{ Debt-Assets Ratio } & Low & $\sim 0.379$ & \multirow{3}{*}{3 equal frequency } \\
\hline & & Mid & $0.379 \sim 0.573$ & \\
\hline & & High & $0.573 \sim$ & \\
\hline \multirow{2}{*}{ Chaebol } & \multirow{2}{*}{ Chaebol or Non-Chaebol } & Yes & 0 & \multirow{2}{*}{ Binary } \\
\hline & & No & 1 & \\
\hline
\end{tabular}

\section{RESULTS OF ANALYSIS}

\subsection{Descriptive Statistics of Variables}

Table 3 shows descriptive statistics of the variables used in this study. On Panel A, the mean (median) of firm value (TobinQ) is $1.047(0.876)$, showing that the mean is larger than the median, which indicates that the value of the samples is right skewed. The mean (median) of return on assets (ROA) is $0.035(0.038)$, showing that the net income of the companies included in this study is approx. $3.5 \%$ of total assets. The mean (median) of company size (Size) is 26.453 (26.158). The mean (median) of debt ratio (LEV) is $0.487(0.476)$, showing that the debt of the companies is approx. $49 \%$ of total assets. The average operating cash flow (OCF) is 0.053 , showing that the companies generally have positive cash flow in sales activity. The mean (median) of growth rate of sales (Growth), which represents the possibility of companies' future growth, is 0.059 (0.008), and that of R\&D expenditure ratio (RNDtoS) is 0.011 (0.004). In addition, the mean (median) of capital intensity (Cap_Intensity) is $0.354(0.345)$. Lastly, the mean of being a chaebol company (Chaebol) is 0.210 , showing that $21 \%$ of the companies included in this study are chaebol companies.

On Panel B, the results of analyzing differences in firm value and financial characteristic variables between chaebol companies and non-chaebol companies are shown. Examining the results, the mean difference of firm value (TobinQ) is 0.238 , where chaebol companies have significantly higher values than non-chaebol companies. This indicates that chaebol companies within a chaebol group effectively exchange and use human and material resources and thereby create a synergy effect, receiving great assessment from the market. Besides, the mean difference of return on assets (ROA) is 0.016 , where chaebol companies also have significantly higher values than non-chaebol companies. This result implies that chaebol companies are maintaining their monopoly status in each industry field, which leads to high profitability. Company size (Size) of chaebol companies is generally larger than non-chaebol companies, indicating that chaebol companies are taking advantage of economy of scale in the market and thereby their operating cash flow (OCF) is 0.028 higher than that of non-chaebol companies. Additionally, the mean difference of R\&D expenditure ratio (RNDtoS) of chaebol companies is -0.003, implying that chaebol companies 
invest smaller capital compared to non-chaebol companies. This result indicates that chaebol companies within a chaebol group prevent an unnecessary waste of resources by sharing the outcomes of R\&D.

Besides, on Panel B, the mean difference of debt ratio (LEV) is 0.051 , which is statistically significant, indicating that chaebol companies' debt ratio is higher than that of non-chaebol companies. This result corresponds with that of preceding studies (Stein, 1997; Kim et al., 2012). In other words, considering the characteristics of capital finance and capital structure, chaebol companies are not influenced much by external factors. Especially, while chaebol companies have the capital market within their chaebol group, non-chaebol companies raise funds from external financial institutions (e.g. banks, outside institutional investors, etc.). Thus, as non-chaebol companies are greatly exposed to external influence in terms of fund raising compared to chaebol companies, it is highly likely that they would have a low debt ratio considering their capital structure.

On the other hand, regarding capital finance, chaebol companies are capable not only of requiring the government to relieve restriction on borrowing, but also of relieving the limitation on liquidity through guarantee for obligation among themselves or internal fund raising (Stein, 1997). As a result, chaebol companies can use relatively more debt than non-chaebol companies (Kim et al., 2012).

Table 3. Descriptive Statistics of Variables

\begin{tabular}{|c|c|c|c|c|c|}
\hline \multicolumn{6}{|c|}{ Panel A. All Sample } \\
\hline Variables & Mean & Std. Dev. & $25 \%$ & Median & $75 \%$ \\
\hline TobinQ & 1.047 & 0.803 & 0.705 & 0.876 & 1.144 \\
\hline ROA & 0.035 & 0.316 & 0.008 & 0.038 & 0.075 \\
\hline $\mathrm{OCF}$ & 0.053 & 0.100 & 0.004 & 0.051 & 0.104 \\
\hline Growth & 0.059 & 1.101 & -0.097 & 0.008 & 0.111 \\
\hline Cap_Intensity & 0.354 & 0.194 & 0.211 & 0.345 & 0.482 \\
\hline RNDtoS & 0.011 & 0.022 & 0.000 & 0.004 & 0.005 \\
\hline Size & 26.453 & 1.544 & 25.372 & 26.158 & 27.282 \\
\hline LEV & 0.487 & 0.460 & 0.323 & 0.476 & 0.624 \\
\hline Chaebol & 0.210 & 0.407 & 0.000 & 0.000 & 0.000 \\
\hline
\end{tabular}

Panel B. Chaebol vs. Non-Chaebol

\begin{tabular}{|c|c|c|c|}
\hline \multirow{2}{*}{ Variables } & \multicolumn{2}{|c|}{ Mean } & \multirow{2}{*}{ Mean Difference } \\
\hline & Chaebol & Non-Chaebol & \\
\hline TobinQ & 1.235 & 0.997 & $0.238^{* * *}$ \\
\hline ROA & 0.048 & 0.032 & $0.016^{*}$ \\
\hline OCF & 0.075 & 0.047 & $0.028^{* * *}$ \\
\hline Growth & 0.068 & 0.057 & 0.011 \\
\hline Cap_Intensity & 0.361 & 0.351 & $0.010^{*}$ \\
\hline RNDtoS & 0.009 & 0.012 & $-0.003^{* * *}$ \\
\hline Size & 28.149 & 26.002 & $2.147^{* * *}$ \\
\hline LEV & 0.528 & 0.477 & $0.051^{* * *}$ \\
\hline
\end{tabular}

Note: ${ }^{*}, * * * * *$ indicate significance at the $10 \%, 5 \%$, and $1 \%$ level, respectively(two-tailed test).

\subsection{The Weight of Chaebol Companies Included in Each Variable}

Firm value and financial characteristic variables used in this study are categorized, and then a distribution map of being a chaebol company for each variable is made, which is shown in Figure 1. As described in Table 1, all the variables are categorized into three groups at equal frequency except for being a chaebol company (Chaebol) and R\&D expenditure ratio (RNDtoS). The samples of this study are 6,602 firm-years, and the sample size of each group is shown in Figure 1. In Table 2, the mean of each variable is shown based on chaebol companies and non-chaebol companies, while Figure 1 shows the weights of chaebol companies and non-chaebol companies included in each variable. For example, as operating cash flow (OCF) on the upper left corner is categorized into three groups at equal frequency, it has three bars, with the left bar representing a group having low operating cash flow (Low, [ 0.021], 2,201 firm-years), the middle bar middle (Mid, [0.021 0.082], 2,201 firm-years), and the right bar high 
(High, [0.082 ], 2,200 firm-years). It can be confirmed that a group with higher operating cash flow (OCF) has a higher weight of chaebol companies.

Looking at being a chaebol company (Chaebol) on the lower right corner, the blue color represents non-chaebol companies (5,215 firm-years) and the red color shows chaebol companies (1,387 firm-years). In addition, as also shown in Table 2, groups with high firm value (TobinQ), company size (Size), debt ratio (LEV), or return on assets (ROA) appear to be red, indicating the high weights of chaebol companies.

Figure 1. Distribution Map of Chaebol Companies Included in Each Variable

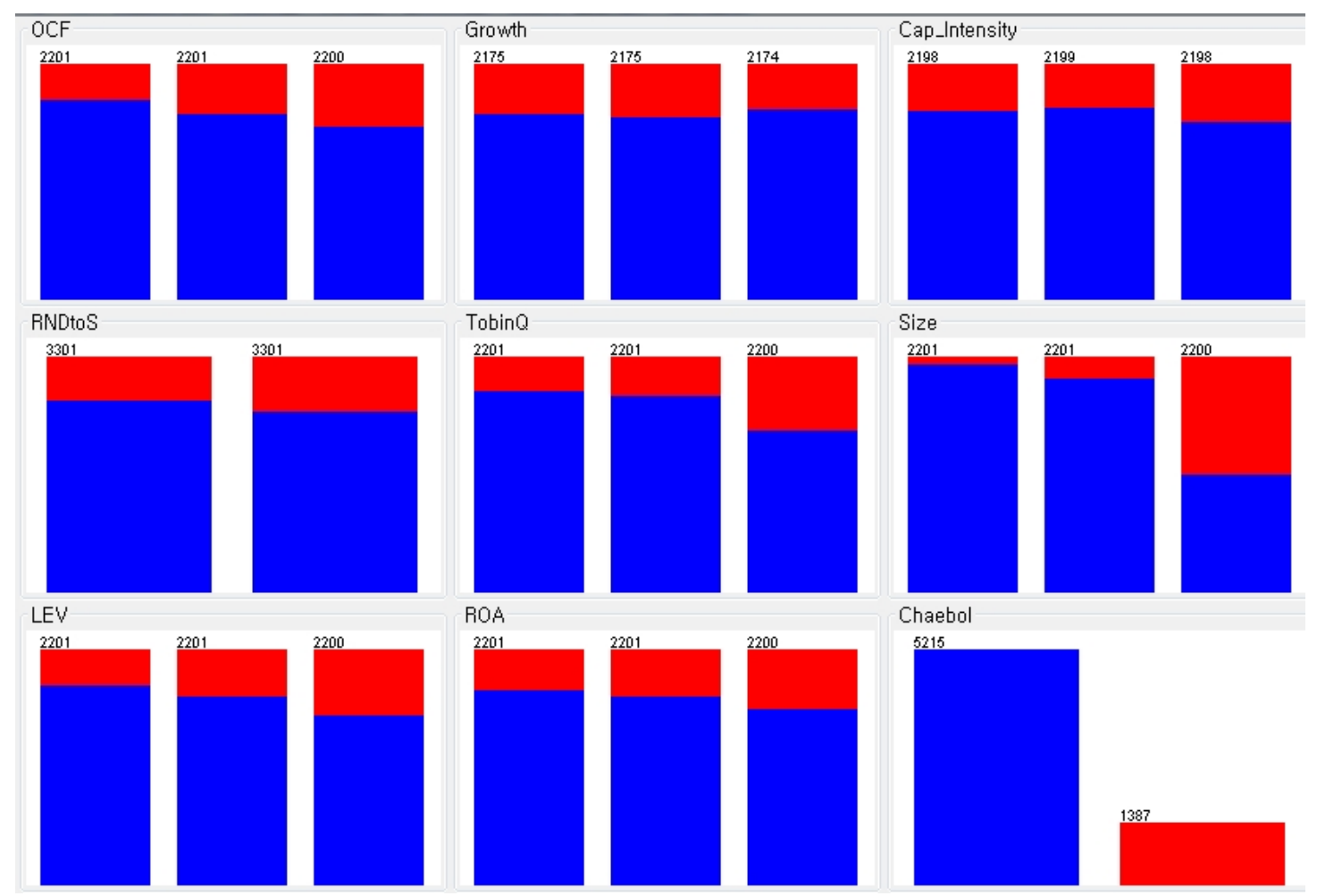

\subsection{Causal Relationships between Variables Based on Bayesian Network}

Bayesian Network can overcome the limitation caused by the linearity between explanatory and dependent variables assumed in the typical regression analysis. As it can show not only the relationships between explanatory and dependent variables but also the causal relationships between explanatory variables, it can reflect the complex real world better (Neapolitan, 2004). The causal relationships between the variables used in this study are shown in Figure 2 .

As Figure 2 shows, all the financial characteristics used in this study turns out to directly influence firm value (TobinQ). That is, the company characteristic variables directly influencing firm value included operating cash flow (OCF), return on assets (ROA), growth rate of sales (Growth), debt ratio (LEV), company size (Size), R\&D expenditure ratio (RNDtoS), capital intensity (Cap_Intensity), and being a chaebol company (Chaebol). Besides, examining the causal relationships between financial characteristics, operating cash flow (OCF) has direct causal relationships with return on assets(ROA), capital intensity (Cap_Intensity), and growth rate of sales (Growth). In addition, capital intensity (Cap Intensity) shows direct causal relationships with company size (Size) and R\&D expenditure ratio (RNDtoS). Being a chaebol company (Chaebol), the main variable of interest in this study, have direct causal relationships with company size (Size) and firm value (TobinQ). 
The primary goal of this study is, by setting firm value (TobinQ) as a dependent variable and using a causal relationship graph, to examine the effects of financial characteristic variables and being a chaebol company (Chaebol) on firm value (TobinQ). On the mean difference analysis showed in Table 2, being a chaebol company (Chaebol) shows significant differences in the mean differences of financial characteristic variables (e.g. return on assets, operating cash flow, capital intensity, R\&D expenditure ratio, company size, and debt ratio). However, according to the analysis using Bayesian Network, only company size (Size) have a direct causal relationship with being a chaebol company (Chaebol) regarding firm value (TobinQ).

Figure 2. Causal Relationships between Variables Derived Based on Bayesian Network

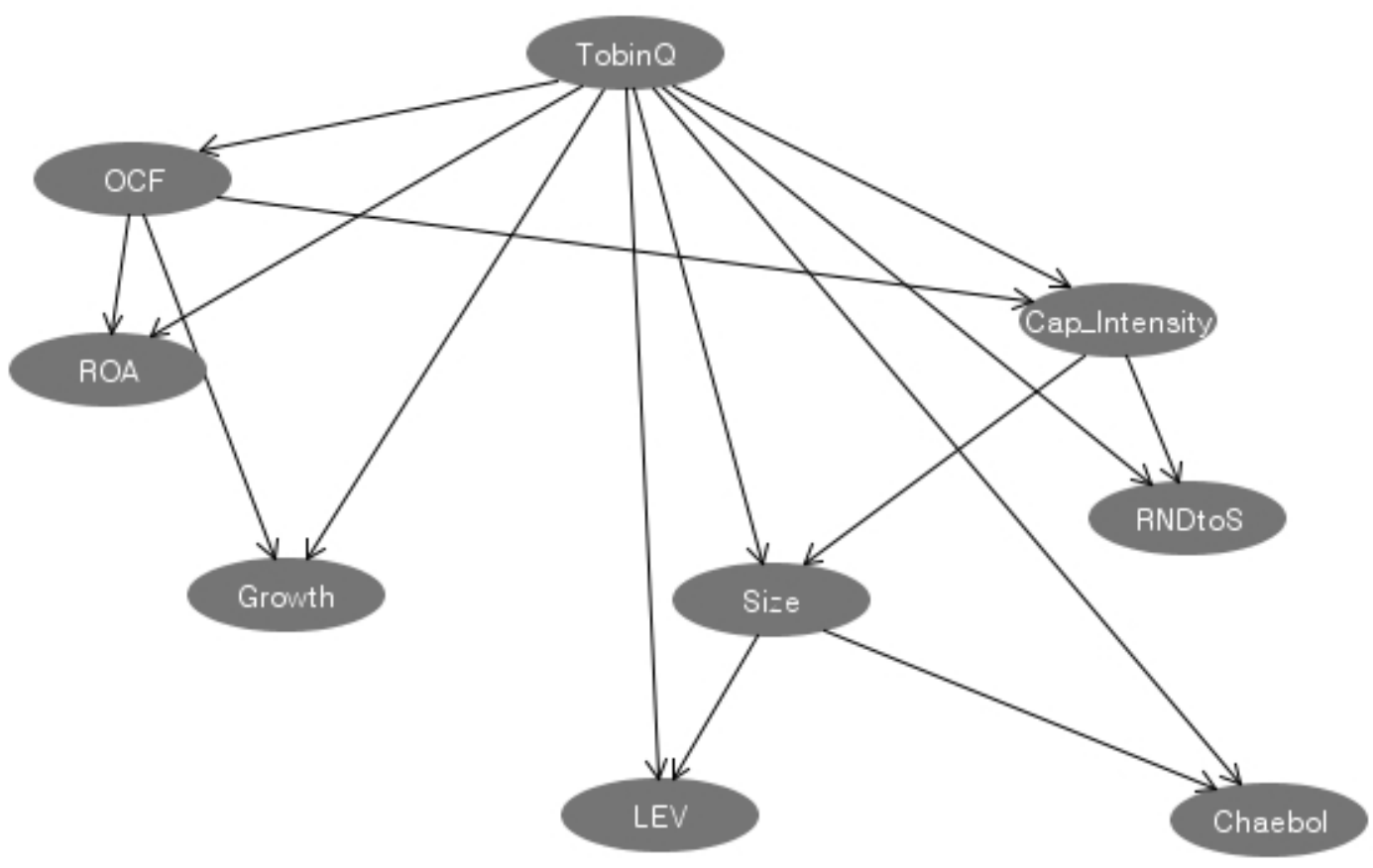

\subsection{Sensitivity Analysis}

The merit of What-If analysis is to consider diverse situations that could happen in the various types of the real world and thereby to predict the results. The causal relationship graph shown in Figure 2 helps grasp what financial characteristic variables would lead to firm value through direct and indirect causal relationships with other variables, which is practically very useful. In other words, sensitivity analysis could be a highly efficient decision-making tool for many decision makers.

Figure 3 shows the results of conducting sensitivity analysis such as What-If analysis by inputting prior probability and posterior probability of variables based on Bayesian Network. Panel A represents prior probability on the causal relationship graph derived from Bayesian Network. The variables are classified into three groups except for R\&D expenditure ratio (RNDtoS) and being a chaebol company (Chaebol). Thus, prior probability of Low, Mid, and High groups is approx. $33.3 \%$, respectively. On the other hand, $\mathrm{R} \& \mathrm{D}$ expenditure ratio (RNDtoS) is divided into two groups based on the median, Low and High groups, and each group showed $50 \%$ prior probability, respectively. Similarly, as for being a chaebol company (Chaebol), prior probability of chaebol companies (Yes) is $21.04 \%$ and that of non-chaebol companies (No) is $78.95 \%$. These values are the same as those suggested by descriptive statistics shown in Table 2.

Panel B represents how posterior probability of each variable would change in case of chaebol companies. First, the probability of being included in a group having low firm value (Low) decreased from $33.33 \%$ to $23.53 \%$, while that of being included in a group having high firm value (High) increased from $33.32 \%$ to $49.90 \%$. This result indicates 
that as chaebol companies exert their monopoly status in each industry field, their competitiveness becomes acknowledged in the capital market. In addition, as for company size (Size) having a direct causal relationship with being a chaebol company (Chaebol), the probability of being included in a group having small company size (Low) greatly decreases from $33.33 \%$ to $5.78 \%$, while that of being included in a group having large company size (High) drastically increases from $33.32 \%$ to $78.94 \%$. This result proves that most chaebol companies are securing their own competitiveness in the market through economy of scale. The change in posterior probability of debt ratio (Lev) or return on assets (ROA) is smaller than that of firm value (TobinQ) or company size (Size) having a direct causal relationship with being a chaebol company (Chaebol), which would be because they have indirect causal relationships with being a chaebol company (Chaebol).

A high debt ratio raises future uncertainty and possibility of bankruptcy, reducing firm value (Trueman \& Titman, 1988). Thus, as shown in Panel C, when debt ratio (Lev) is high, the probability of being included in a group having low firm value (Low) increased from $33.33 \%$ to $48.01 \%$, while that of being included in a group having high firm value (High) decreases from $33.33 \%$ to $22.24 \%$. However, when company size (Size) is large at the same time (when company size is higher than 26.805 in Table 1), the probability of being included in a group having low firm value (Low) decreases from $48.01 \%$ to $39.90 \%$, while that of being included in a group having high firm value (High) increases from $22.24 \%$ to $27.42 \%$. These results imply that even when a company's debt ratio is high, if its size is large, the tendency of reduction in firm value could be partially offset.

Likewise, looking at Panel E, when R\&D expenditure ratio (RNDtoS) is high, the probability of being included in a group having high firm value (High) slightly increases from $33.33 \%$ to $37.8 \%$. Besides, when chaebol companies (Chaebol) raises R\&D expenditure ratio (RNDtoS), the probability of being included in a group having high firm value (High) drastically increases up to $55.17 \%$ (Panel F). These results show that chaebol companies have a higher level of effectiveness of R\&D than non-chaebol companies. For example, R\&D performed by one chaebol company would promote information sharing with other chaebol companies of the chaebol group, having positive effects on firm value of all the chaebol companies within the chaebol group. On the contrary, when non-chaebol companies (Non-Chaebol) raised R\&D expenditure ratio (RNDtoS), the probability of being included in a group having high firm value (High) is only $33.01 \%$, showing little shift (Panel G).

Figure 3. Sensitivity Analysis Reflecting the Real World

Panel A. Prior Probability on the Causal Relationship Graph Derived from Bayesian Network

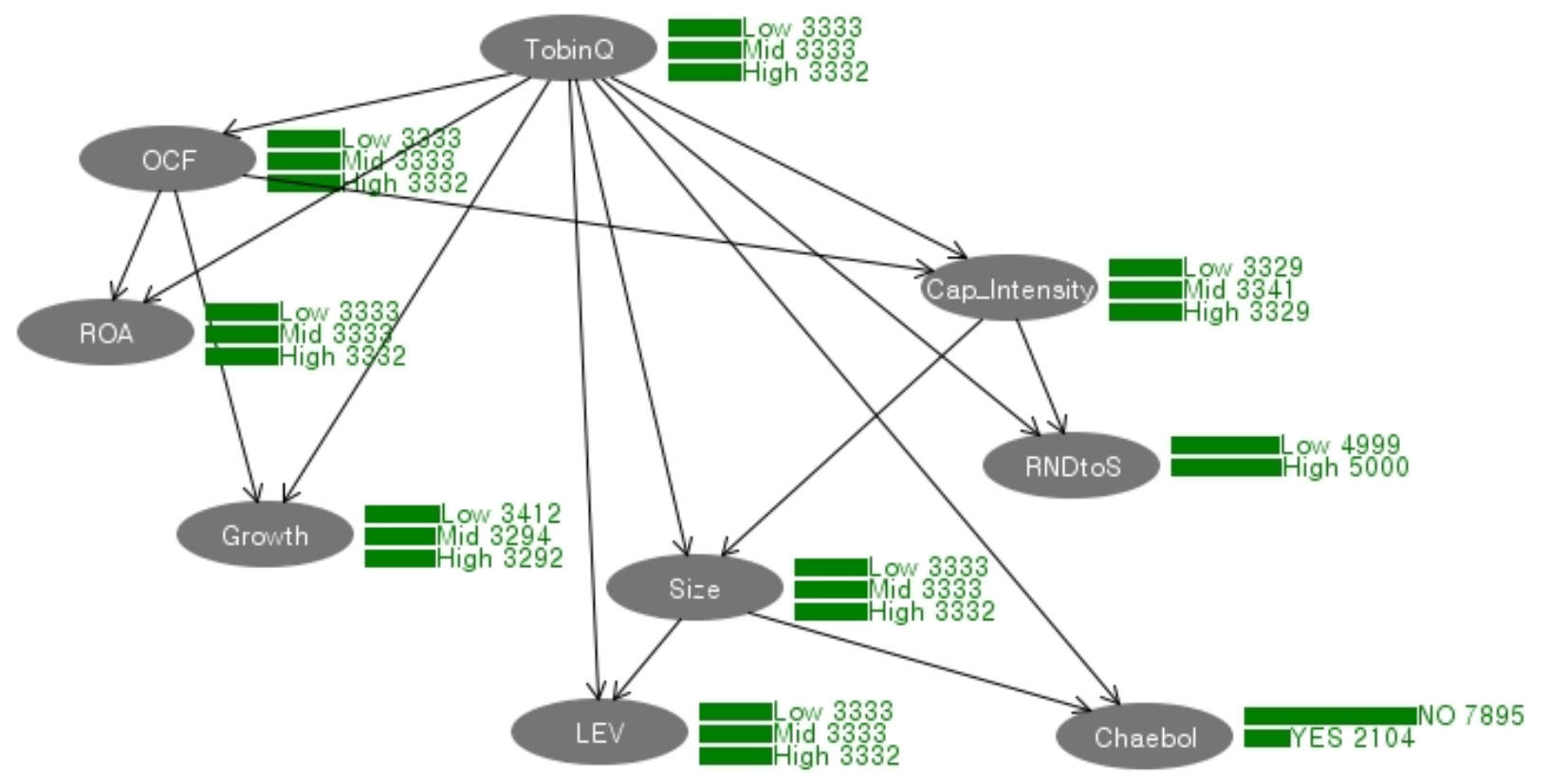


(Figure 3 continued)

Panel B. Posterior Probability of Financial Characteristics in Case of Chaebol Companies

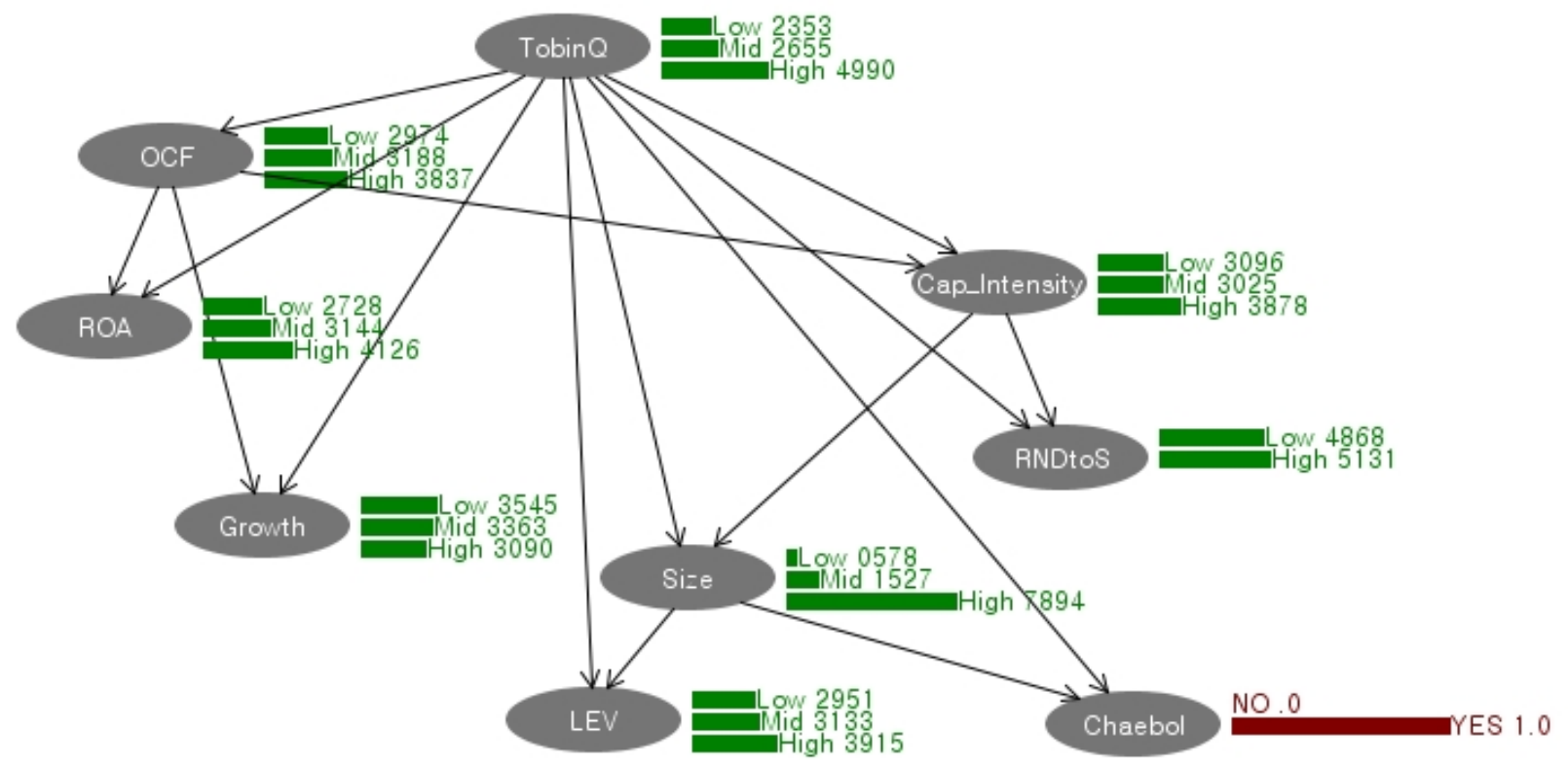

Panel C. Posterior Probability of Financial Characteristics When Debt Ratio Is High

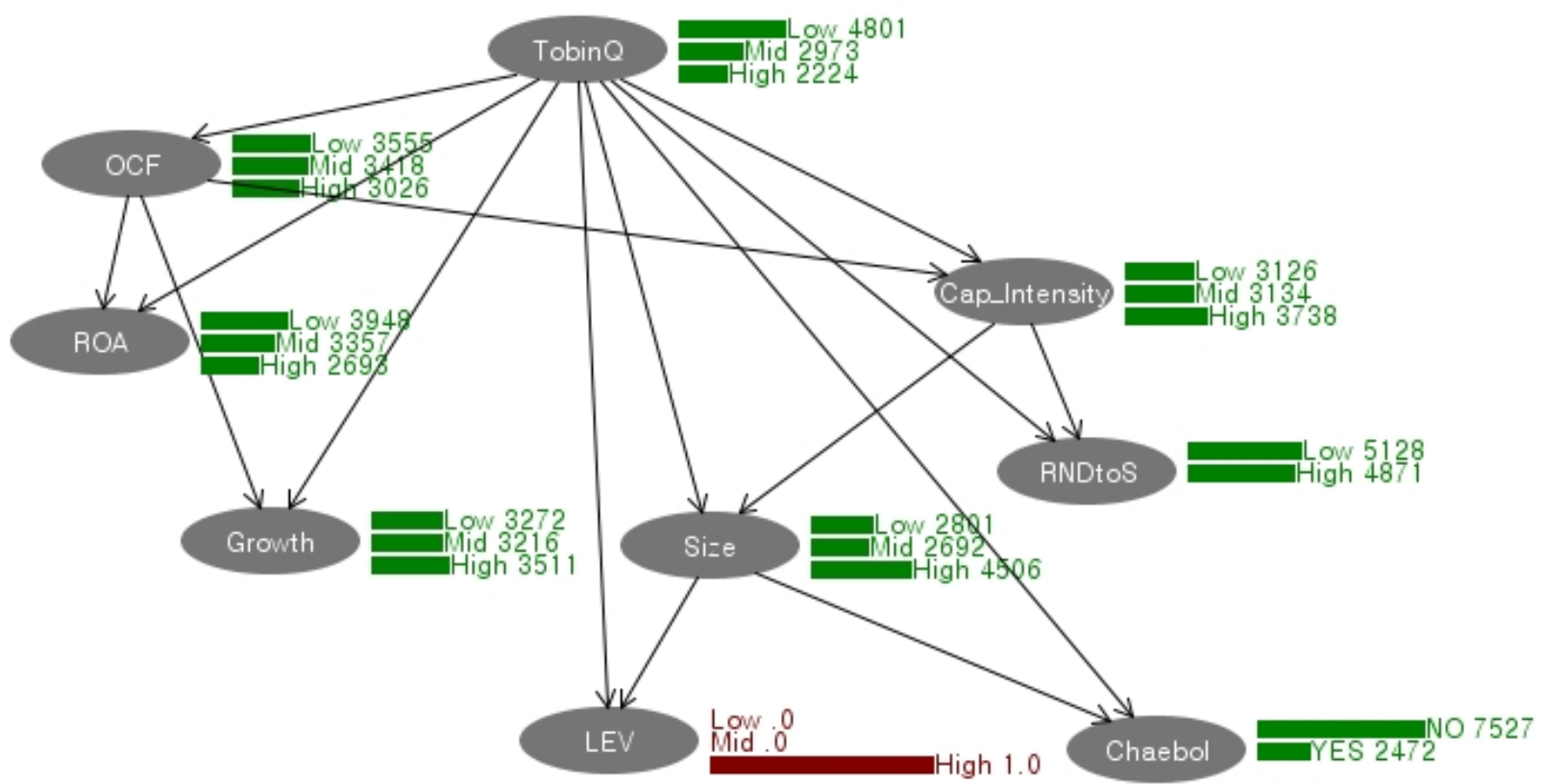


(Figure 3 continued)

Panel D. Posterior Probability of Financial Characteristics When Debt Ratio Is High and Company Size Is Large Simultaneously

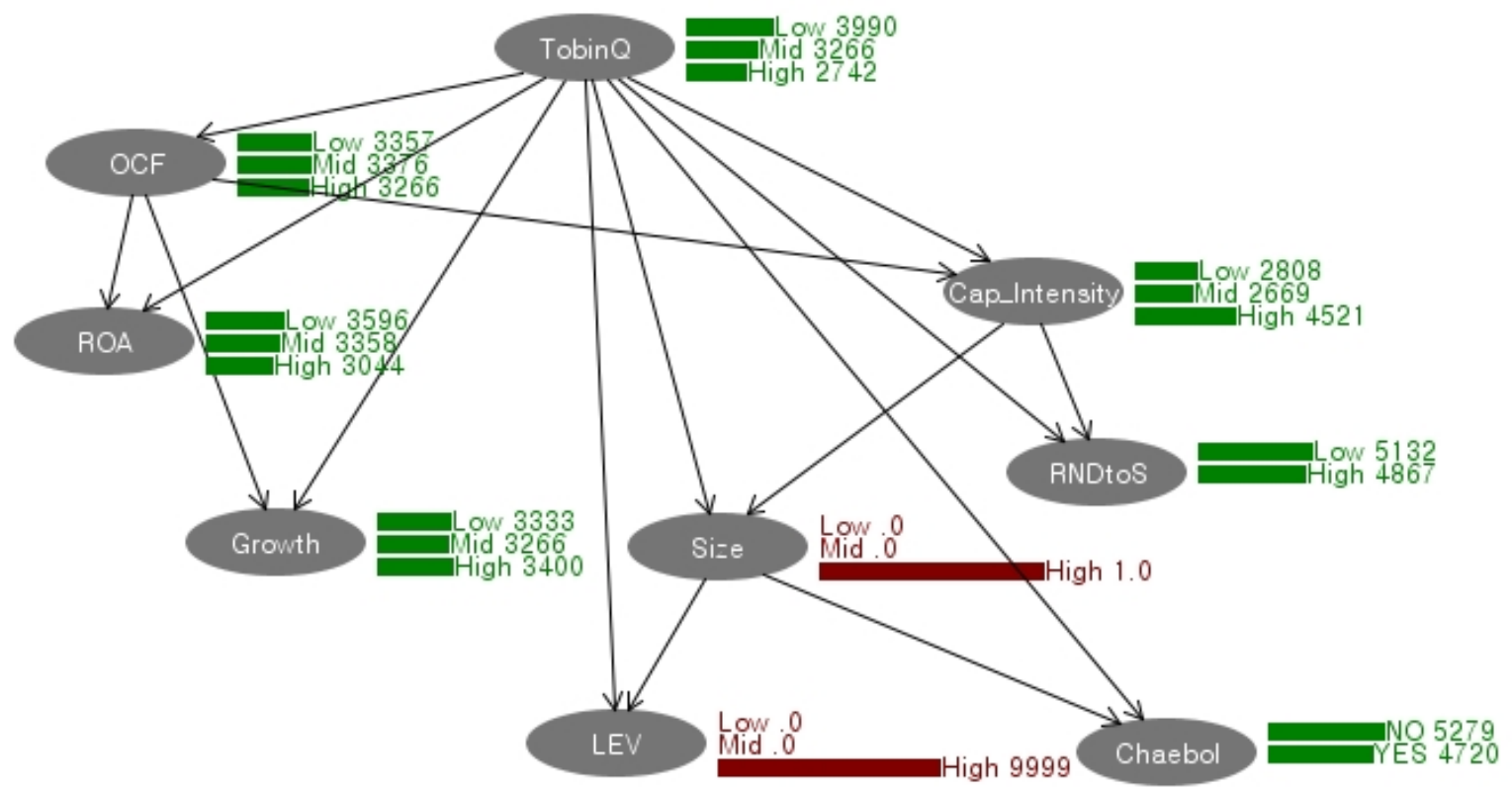

Panel E. Posterior Probability of Financial Characteristics When R\&D Expenditure Ratio Is High

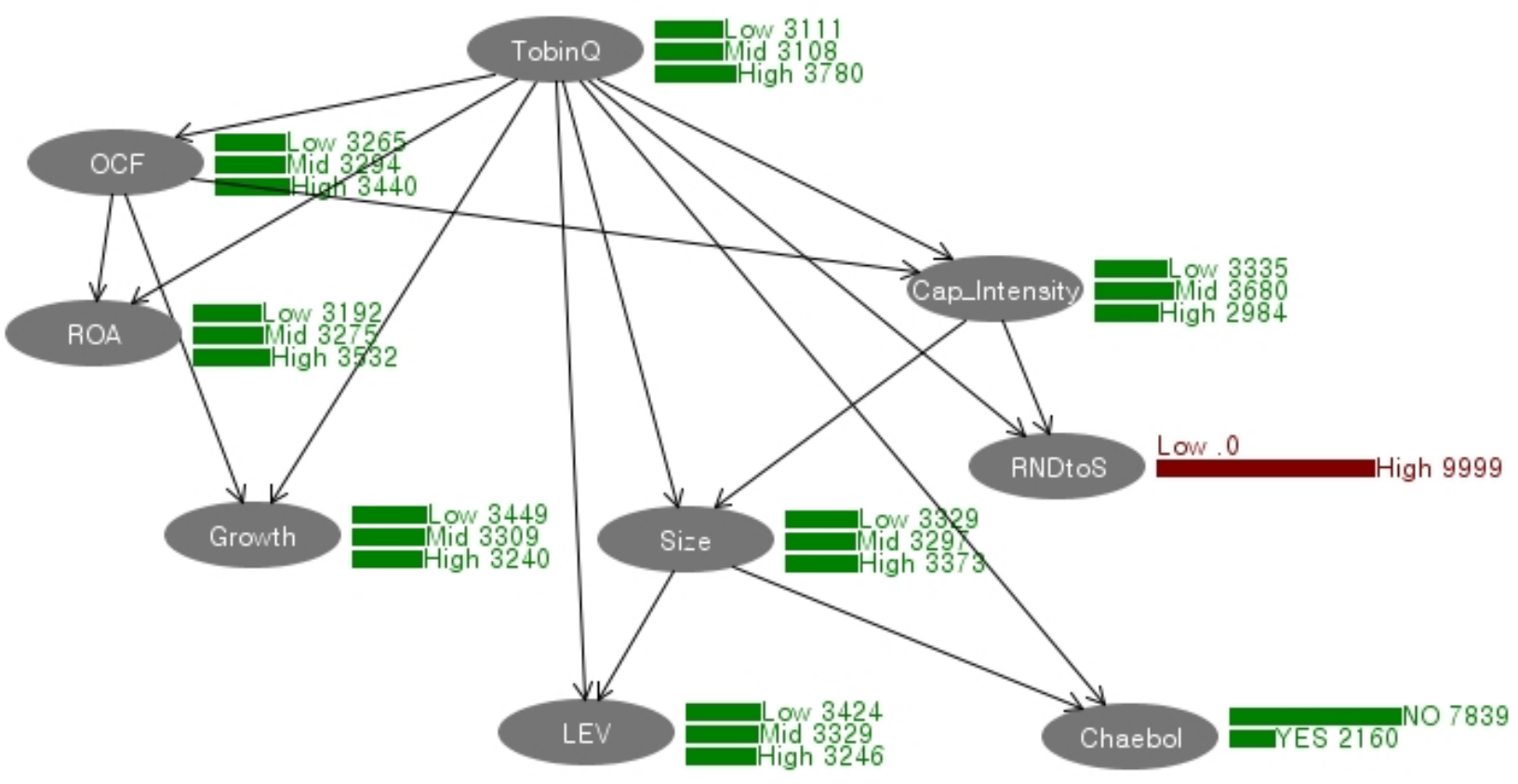


(Figure 3 continued)

Panel F. Posterior Probability of Financial Characteristics When Chaebol Companies Raise R\&D Expenditure Ratio

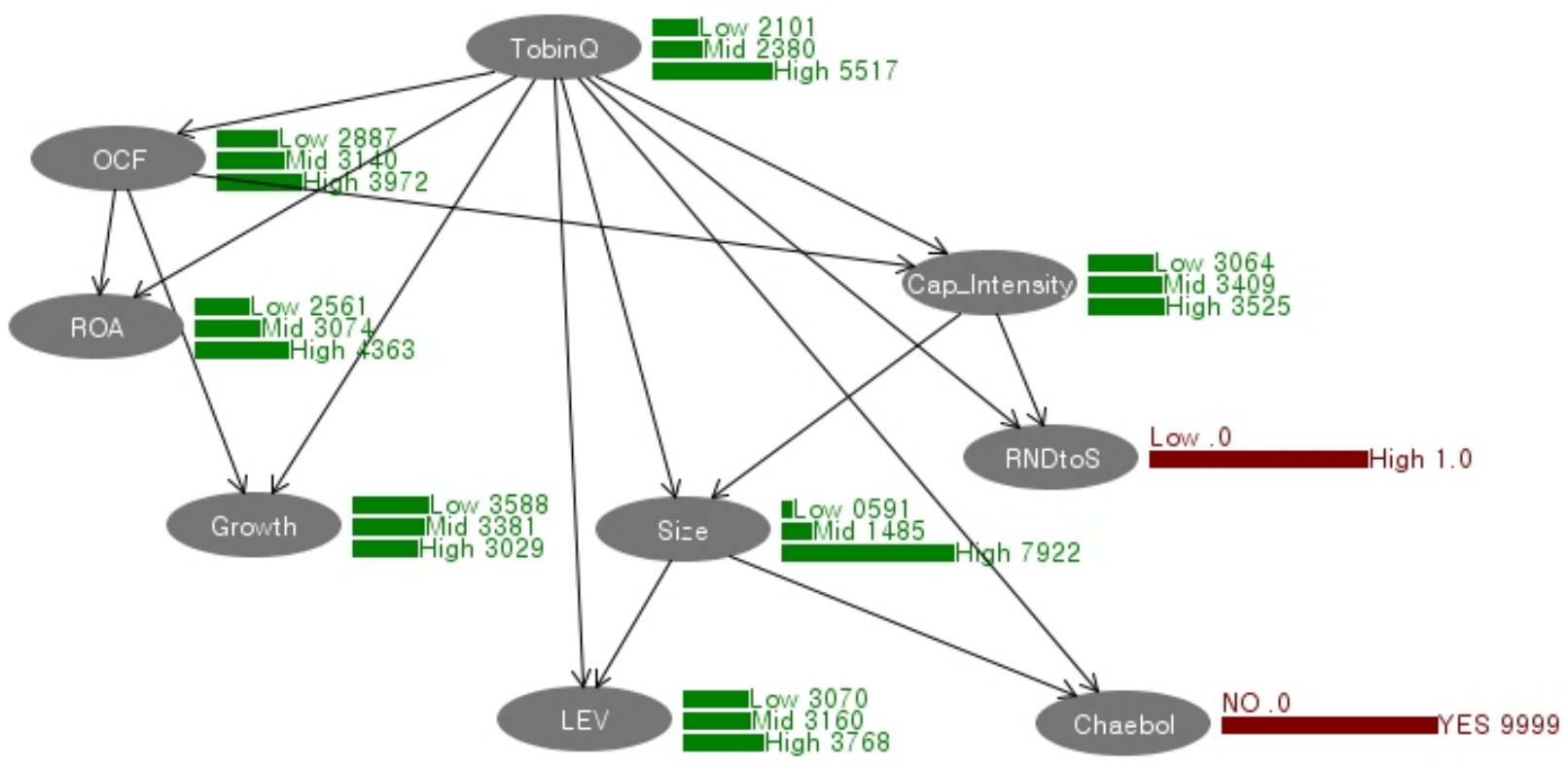

Panel G. Posterior Probability of Financial Characteristics When Non-Chaebol Companies Raise R\&D Expenditure Ratio

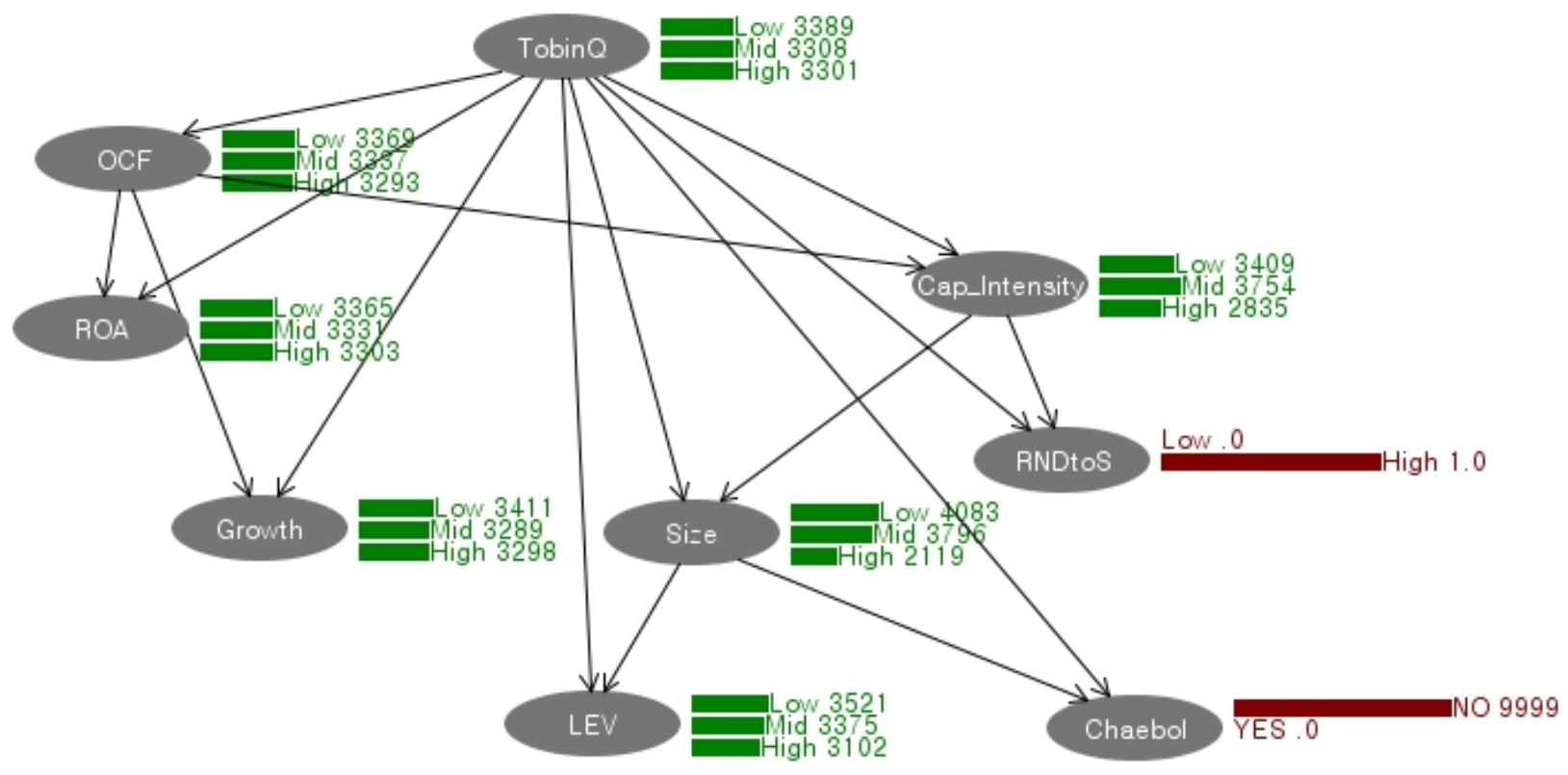

\section{CONCLUSION}

This study, by using Bayesian Network, examined the effects of chaebol companies and their financial characteristics on firm value. Specifically, this study attempts to help accounting information users in their decisionmaking by using Bayesian Network and deriving causal relationships between financial characteristics and firm 
value. To this end, by targeting 6,602 firm-years meeting certain conditions of data publically announced by FTC from 2006 to 2015 (e.g. a group of large-size companies, a group of companies limited to make mutual investment, etc.) and of financial information from New KISVALUE of Nice Information Service, this study extracts financial characteristics explaining firm value and examines the relationships between these characteristics and Chaebol companies using Bayesian Network and sensitivity analysis. The study results can be summarized as below.

First, as a result of deriving a causal relationship graph representing firm value and financial characteristics, the company characteristics directly influencing firm value (TobinQ) included operating cash flow (OCF), return on assets (ROA), growth rate of sales (Growth), debt ratio (LEV), company size (Size), R\&D expenditure ratio (RNDtoS), capital intensity (Cap_Intensity), and being a chaebol company (Chaebol). Besides, it turns out that there would be certain causal relationships also between company characteristic variables. For example, operating cash flow (OCF) shows direct causal relationships with return on assets (ROA), capital intensity (Cap_Intensity), and growth rate of sales (Growth), where capital intensity (Cap_Intensity) have direct causal relationships with company size (Size) and R\&D expenditure ratio (RNDtoS). In addition, regarding firm value (TobinQ), only company size (Size) has a direct causal relationship with being a chaebol company (Chaebol).

Second, based on the causal relationship graph using sensitivity analysis and Bayesian Network, this study analyzed the effects of the change in prior probability of certain variables on other variables, and the results turn out to be significant. For example, as for chaebol companies, the probability of being included in a group having low firm value (TobinQ) decreases, while that of being included in a group having high firm value (TobinQ) dramatically increases. In addition, regarding company size (Size), their probability of being included in a group having small company size (Size) drastically decreases, while that of being included in a group having large company size (Size) increases over two times. Besides, when debt ratio (Lev) is high, the probability of being included in a group having low firm value (TobinQ) increases, while that of being included in a group having high firm value (TobinQ) decreases. However, when company size (Size) is large simultaneously, the probability of being included in a group having low firm value (TobinQ) decreases, while that of being included in a group having high firm value (TobinQ) increases. Lastly, when $R \& D$ expenditure ratio (RNDtoS) is high, the probability of being included in a group having high firm value (TobinQ), their probability of being included in a group having high firm value (TobinQ) drastically increases. On the other hand, when non-chaebol companies raise R\&D expenditure ratio (RNDtoS), there is little shift in their probability of being included in a group having high company value (TobinQ).

Compared to preceding studies, this study has implications as follows. First, by using Markov Blanket of Bayesian Network, it extracts company characteristic variables influencing firm value. In addition, by representing the causal relationships existing between characteristic variables on a graph, it provided useful information for managers to decide necessary things in improving firm value. As the results of this study have not been provided before by existing studies, this study will contribute to improvement of firm value in the future.

Second, this study conducts sensitivity analysis using the causal relationships between firm value, being a chaebol company, and company characteristic variables included in Markov Blanket. This sensitivity analysis would be useful in examining what company characteristic variables should be changed to improve firm value. In other words, as the sensitivity analysis of this study has not been conducted in existing studies dealing with firm value and chaebol companies, it is a contribution provided only by this study.

Lastly, the sensitivity analysis conducted in this study to derive company characteristic variables directly and indirectly influencing firm value based on Bayesian Network and to analyze their causal relationships not only will help managers in their decision-making to improve firm value but also will become a very strong decision-making tool for various accounting information users. For example, it will provide useful information for investors regarding what company characteristics they should focus on when they invest in certain companies. 


\section{ACKNOWLEDGMENT}

This work was supported by 2016 Hannam University Research Fund.

\section{AUTHOR BIOGRAPHIES}

Dr. Eun-Jung Sun is an assistant professor at department of accounting, Hannam University, South Korea. Research interests included management information system, management \& cost accounting, and government accounting (First author).

Dr. Sung-Jin Park is an assistant professor at department of business administration, Sungshin Women's University, South Korea. His research focuses on financial accounting, auditing, management information system, management \& cost accounting, taxation (corresponding author).

\section{REFERENCES}

Baginski, S., Lorek, K. Willinger, G. L. \& Branson, B. (1999). The relationship between economic characteristics and alternative annual earnings persistence measures. The Accounting Review, 74, 105-120.

Berger, P. G., \& Ofek, E. (1995). Diversification's effect on firm value. Journal of Financial Economics, 37, 39-65.

Campbell, T. L., \& Keys, P. Y. (2002). Corporate governance in South Korea: The Chaebol experience. Journal of Corporate Finance, 8, 373-391.

Chang, J. J., \& Shin, H. H. (2006). Governance system effectiveness following the crisis: The case of Korean Business Group Headquarters. Corporate Governance, 14(2), 85-97.

Chang, J. J., \& Hong, J. (2000). Economic performance of group-affiliated companies in Korea: Intragroup resource sharing and internal business transactions. Academy of Management Journal, 43(3), 429-448.

Chang, S. J. (2003). Ownership structure, expropriation, and performance of group-affiliated companies in Korea. Academy of Management Journal, 46(2), 238-253.

Chung, K. H., \& Pruitt, S. W. (1994). A simple approximation of Tobin's Q. Financial Management, 23(3), 70-74.

Francis, J., \& Schipper, K. (1999). Have financial statements lost their relevance? Journal of Accounting Research, 37, $319-352$.

Jang, G. I., \& Choi, H. S. (2010). The relation between corporate social responsibility and financial performance. Korea Business Review, 23(2), 633-648.

Jensen, M. C., \& Meckling, W. (1976). Theory of the firm: Managerial behavior, agency costs, and ownership structure. Journal of Financial Economics, 3, 305-360.

Kang, C., Lee, J. \& Choi, E. (2009). The effect of corporate governance on firm valuation: A comparative study of Korean Chaebols. Journal of Industrial Economics and Business, 22(3), 995-1016.

Kang, M. H. (1999). Chaebol reformation and corporate governance. Journal of Korean Economy Studies, 3(1), $113-151$.

Klein, A. (2002). Audit committee, board of director characteristics, and earnings management, Journal of Accounting and Economics 33, 375-400.

Khanna, t., \& Palepu, K. (2000). is group affiliation profitable in emerging markets? an analysis of diversified Indian business groups. Journal of Finance, 55(2), 867-891.

Kim, S. J., Park, J. H. \& Kim, C. S. (2012). CEO utilization and weeding-out in Korean business groups: A comparative study of Chaebol and non-Chaebol groups. Korean Management Review, 41(3), 483-510.

Lev, B. (1983). Some economic determinants of the time-series properties of earnings. Journal of Accounting and Economics, 5 , 31-38.

Lewellen, w. g. (1971). A pure financial rationale for the conglomerate merger. Journal of Finance, 26, 521-537.

McNeil, C., Niehaus, G. \& Powers, E. (2004). Management turnover in subsidiaries of conglomerates versus stand-alone firms. Journal of Financial Economics, 72(1), 63-96.

Na, Y., \& Hong, S. H. (2011). An empirical analysis on value relevance of corporate social responsibility activities by firm size. Korea Journal of Accounting, 20(5), 125-160.

Neapolitan, R. E. (2004). Learning Bayesian networks. Pearson Prentice Hall. Upper Saddle River, NJ.

Park, J. H., Sung, Y. D. \& Jung, M. K. (2010). The role of Chaebol on CEO turnover in Korean corporate governance. Journal of Strategic Management, 13(3), 89-119.

Pastor, L., \& Veronesi, P. (2003). Stock valuation and learning about profitability. Journal of Finance, 58, $1749-1789$.

Rountree, B., Weston, J. \& Allayannis, G. (2008). Do investors value smooth performance? Journal of Financial Economics, 90 , 237-251.

Shin, H. H., \& Chang, J. H. (2005). An analysis of the determinants of CEO turnover: Firm performance, professional CEO, and business group. Korean Management Review, 34(1), 289-311.

Song, I. M., Yun, S. S. \& Choi, K. (2014). Intermediate accounting. ShinYoungSa, Mapo, Seoul. 
Stein, J. C. (1997). Internal capital markets and the competition for corporate resources. Journal of Finance, 52, 111-133.

Stulz, R. M. (1990). Managerial control of voting rights financing policies and market for corporate control. Journal of Financial Economics, 20, 25-54.

Trueman, B., \& Titman, S. (1988). An explanation for accounting smoothing. Journal of Accounting Research, 26, $127-139$. 